\title{
The MVA-NP+M Influenza Vaccine did work. It may help defeat COVID.
}

\author{
John SW Gillis, $\mathrm{PhD}^{1 *}$ \\ ${ }^{1}$ Science and Technology Studies, St Thomas University, Fredericton NB Canada E3B \\ $5 \mathrm{G} 3$
}

*Correspondence: jgillis@stu.ca

Many scientists are developing COVID-19 vaccines. However, we need effective influenza vaccines as well. Otherwise, a second wave of COVID will be a double whammy.

Here I show that the results of Davenport et al [1] are significantly better than reported in the original study. 


\section{Experiment 1}

\section{Method and Results}

I used the 6-gene profile data from Davenport et al [1] and subtracted the mean of 11 vaccinated participants from the mean of 11 unvaccinated participants. The results are shown below:

Gene Name

Unvaccinated minus Vaccinated group

CCL2

.701

LAMP3

.561

MT1G

.642

OAS3

.933

RTP4

.376

SEPT4

.446

Fisher's Exact Test $=.012$ 


\section{Experiment 2}

\section{Method and Results}

I used a 19-gene profile from Muller et al [2] with the data of [1] and obtained the following results:

$\begin{array}{ll}\text { Gene Name } & \text { Unvaccinated minus Vaccinated group } \\ \text { CCL2 } & .701 \\ \text { CCL8 } & .630 \\ \text { CXCL10 } & .269 \\ \text { HERC5 } & .481 \\ \text { IFI27 } & .204 \\ \text { IFI44 } & .346 \\ \text { IFI44L } & .658 \\ \text { IFI6 } & .423 \\ \text { IFIT1 } & .390 \\ \text { IFIT3 } & .493 \\ \text { ISG15 } & .723 \\ \text { LAMP3 } & .561 \\ \text { OAS3 } & .933 \\ \text { OASL } & .258 \\ \text { OTOF } & .777 \\ \text { RSAD2 } & .735 \\ \text { SERPING1 } & .398 \\ \text { SPATS2L } & .574 \\ \text { USP18 } & .395\end{array}$

It may be seen that the Unvaccinated participants had higher symptom scores than Vaccinated participants on each gene expression measure. Getting a positive number every time, instead of a negative one, is equivalent to flipping a coin and getting 19 heads in a row.

Fisher's Exact Test $=.0000019073$ 


\section{Discussion}

Davenport et al [1] concluded that they "did not detect a difference in the gene expression profile between vaccinated and unvaccinated individuals."

Clearly, the new objective 19-gene profile from [2] did detect a difference.

It did so, even though this profile was derived from a different sample of participants, who had been challenged by H1N1 instead of H3N2 influenza.

Interestingly, the vaccinated group included a participant (Study ID = D) who developed moderate to severe subjective flu symptoms.

Research is underway to understand how to get the MVA-NP+M1 vaccine to work also with individuals like participant $\mathrm{D}$.

Meanwhile, the faster this vaccine is developed, the fewer people will die because they catch both influenza and COVID-19 in the second wave. 


\section{References}

[1] Davenport EE, Antrobus RD, Lillie PJ, Gilbert SC, Knight JC. Transcriptonic profiling facilitates classification of response to influenza challenge. J Mol Med.2015; 93:105-14. doi: 10.1007/s00109-014-1212-8.

[2] Muller J, Parizotto E, Antrobus RD, Francis J, Bunce C, Stranks A. Nicols M, McClainM, Hill AVS, Ramasamy A, Gilbert SC. Development of an objective gene expression panel as an alternative to self-reported symptom scores in human influenza trials. J Transl Med. 2017; 15:134. doi: 10.1186/s12967-017-1235-3. 